\title{
EMOSI POSITIF PADA GURU PENDAMPING SISWA AUTIS PADA SD NEGERI 131/IV KOTA JAMBI
}

\section{POSITIVE EMOTIONS IN TEACHERS ASSISTANCE FOR AUTISTIC STUDENTS AT SD NEGERI 131/IV JAMBI CITY}

\author{
${ }^{1}$ Agnes Rianty, ${ }^{2}$ Dessy Pramudiani \\ ${ }^{12}$ Department of Psychology, Jambi University/ email: agnesriani12@gmail.com
}

\begin{abstract}
Introduction Autistic students had the same rights as normal students in obtained education. Inclusive school are needed for autistic students. Inclusive schools need teacher assisting for accompany the learning process of students with autism. Autistic students had excessive behaviour disorder; self-harm, aggression, and tantrums. The teacher assisting students with autism often feels angry and annoyed when accompanying students with autism. Positive emotions were things that can balanced the emotions of teachers assistance for autistic students in carried out their profession. To find out how to describe positive emotions and the factors that influence the formation of positive emotions in the teachers assistant for autistic students at SD Negeri 131/IV Jambi City.
\end{abstract}

Method Qualitative method with a phenomenological approach. The data was collected use an observation, documentation and in-depth interviews. Use Interpretative phenomenological analysis (IPA). The characteristic of the participant teacher accompanying students with autism in SD Negeri 131/IV Jambi City, aged 25-55 years, faced autistic students directly, and had worked for at least 3 years.

Result An overview the positive emotions in the teacher assistant for autistic students at SD Negeri 131 / IV Jambi City were feels of joy, self-satisfaction, attraction, love, fighting spirit, gratitude, and sympathy. The influence factors consist of environment, cooperation, selfefficacy, work experience, internal motivation, and personality.

Conclusion And Recommendation The four participants have described positive emotions that areable to balance all emotions within themselves for their life and work. This research wasexpected to add insight into positive emotions.

Keywords Positive emotions, teacher assistant, autistic students

\begin{abstract}
ABSTRAK
Pendahuluan Siswa autis memiliki hak yang sama dengan siswa normal dalam memperoleh pendidikan. Sekolah inklusi dibutuhkan untuk siswa autis. Sekolah inklusi memerlukan guru pendamping untuk mendampingi proses belajar siswa autis. Siswa autis memiliki gangguan perilaku berlebihan; melukai diri sendiri, agresif, dan tantrum. Guru pendamping siswa autis kerap merasakan emosi marah dan kesal saat mendampingi siswa autis. Emosi positif menjadi hal yang bisa menyeimbangkan emosi guru pendamping siswa autis dalam menjalani profesinya.
\end{abstract}

Tujuan Untuk mengetahui bagaimana gambaran emosi positif dan faktor yang mempengaruhi pembentukan emosi positif pada guru pendamping siswa autis di SD Negeri 131/IV Kota Jambi.

Metode Metode kualitatif dengan pendekatan fenomenologi. Metode pengumpulan data menggunakan observasi, dokumentasi dan wawancara mendalam. Menggunakan interpretative phenomenilogical analysis (IPA). Karakteristik partisipan guru pendamping siswa autis di SD 
Negeri 131/IV Kota Jambi, berusia 25-55 tahun, menghadapi secara langsung siswa autis, dan sudah bekerja minimal 3 tahun.

Hasil Gambaran emosi positif pada guru pendamping siswa autis di SD Negeri 131/IV Kota Jambi adalah perasaan gembira, kepuasan diri, ketertarikan, cinta, berdaya juang, kebersyukuran, dan simpati. Faktor yang mempengaruhi terdiri dari lingkungan, kerja sama, kemampuan diri, pengalaman kerja, motivasi internal, dan kepribadian.

Kesimpulan Dan Saran Keempat partisipan telah menggambarkan emosi positif yang mampu menyeimbangkan segala emosi dalam dirinya. Penelitian ini diharapkan mampu menambah wawasan mengenai emosi positif.

Kata kunci emosi positif, guru pendamping, siswa autis

\section{PENDAHULUAN}

Pendidikan digunakan sebagai batu loncatan untuk menggali ilmu pengetahuan. Pendidikan terdiri dari tiga jenis, yaitu pendidikan formal, nonformal, dan informal (Khaerani dan Khoiriyah, 2015). Mendiknas menyebutkan terdapat undangundang nomor 70 tahun 2009 tentang Pendidikan Inklusi bagi peserta didik yang memiliki kelainan dan memiliki potensi kecerdasan dan/ atau bakat istimewa. Pendidikan khusus atau luar biasa diberikan kepada peserta didik yang mengalami kesulitan dalam mengikuti proses pembelajaran yang disebabkan karena adanya kelainan atau gangguan fisik, emosi, mental, dan sosial (UU RI No. 70, 2009).

Berdasarkan undang-undang tersebut memperlihatkan bahwasannya anak berkebutuhan khusus memiliki peluang yang selaras untuk mencapai pendidikan serta pengajaran. Adapun pendidikan yang bisa dicapai oleh anak berkebutuhan khusus yaitu pendidikan khusus yang berada pada sistem pendidikan inklusif. (Usop, 2017).

Pendidikan inklusi merupakan bentuk fasilitas pendidikan yang menekankan agar semua anak berkebutuhan khusus bisa mendapatkan layanan di sekolah terdekat serta di tempatkan dalam kelas reguler bersama dengan anak normal lainnya yang memiliki usia yang sama (Saputra, 2016). Pada pendidikan inklusi terdapat sekolah inklusi yang sekolah yang didirikan untuk menjadi tempat mendidik siswa-siswi pada umumnya serta siswa berkebutuhan khusus dengan menyediakan tempat juga bagi siswa berkebutuhan khusus yang mampu didik. Sekolah inklusi juga sebagai sebuah preferensi bagi pendidikan yang tergabung antara siswa reguler dengan siswa berkebutuhan khusus. Dalam sekolah inklusi, fasilitas yang disediakan mencakup layanan sekolah reguler yang terdiri dari siswa reguler dan siswa berkebutuhan khusus yang dimana siswa tersebut di dampingi oleh shadow teacher atau guru pendamping (Murtie, 2017).

Berdasarkan data yang disurvei oleh peneliti di website Direktorat Pembinaan PKLK (Pendidikan Khusus dan Layanan Khusus) Kemendikbud tahun 2019 mengatakan bahwa sekolah inklusi di Kota Jambi berjumlah 60 sekolah inklusi yang terdiri dari sekolah inklusi negeri dan swasta dimulai dari jenjang sekolah dasar hingga sekolah menengah atas. Data tersebut juga menyebutkan sekolah inklusi di Kota Jambi dengan jenjang sekolah dasar berjumlah 32 sekolah inklusi.

Anak berkebutuhan khusus yang terdapat dalam lingkup sekolah inklusi tentu memiliki keberagaman akan kebutuhan. Anak berkebutuhan khusus sendiri merupakan anak dengan kondisi yang memerlukan penanganan khusus yang dimana hal tersebut dikarenakan adanya gangguan perkembangan dan hambatan yang dialami oleh anak. Salah satu kategori anak berkebutuhan khusus ialah autisme. Autisme bukan hanya sebagian peristiwa kecil yang terjadi di kalangan masyarakat Indonesia. Hal tersebut lebih dari yang dibayangkan, autisme kini sudah semakin 
banyak menyebar ke semua kalangan masyarakat di Indonesia, terkhususnya di kalangan anak-anak. Keadaan tersebut dibuktikan dengan angka prevalensi penyandang gangguan autisme yang semakin bertambah di Indonesia setiap tahunnya (Desiningrum, 2016).

Perilaku anak autis tentu memiliki perbedaan anak normal biasanya, mereka yang memiliki gangguan autisme ada yang berperilaku berlebihan seperti cenderung melukai diri sendiri, agresif, mengamuk atau biasa disebut dengan tantrum, melakukan gerakan secara berulang-ulang seperti mengepakkan sayap (Widiastuti, 2014). Penjabaran tersebut diperkuat dengan hasil wawancara yang dilakukan oleh peneliti dengan salah satu guru pendamping siswa autis dengan responden L.

\section{“... saya ada megang beberapa kali anaknya ini sangat sulit sekali, dia sukanya mencubit kita abis itu dia juga mengigit jari dia ada juga dia suka berdiri sambil tepuk tangan jingkrak-jingkrak yang susahnya ya itu kita dibuatnya mungkin harus sabar bener. Kadang ya marah kesel greget itu pastilah ya kalau anak lagi kayak gitu” ( $L$ - diwawancara pada tanggal 31 Januari 2020 Pukul 09:00)}

Perilaku autisme dibagi menjadi dua jenis, yaitu, perilaku yang eksesif (berlebihan) dan perilaku yang defisit (berkekurangan). hiperaktif dan tantrum (mengamuk) berupa menjerit, menggigit, mencakar, memukul, mendorong termasuk kedalam perilaku eksesif (Desiningrum, 2016). Sebagaimana dikatakan oleh responden SF dan $\mathrm{S}$ mengenai perilaku tantrum siswa autis yang sulit di kontrol oleh guru pendamping dan membutuhkan berbagai cara untuk menanganinya.

“...Tantangannya itu disaat dia lagi tantrum misalnya terus dia nya lagi mood nya nggak bagus saat dia nya perilakunya lagi buruk banget kayak gitu. Terus kalo dari awalnya udah buruk itu kita mau fokusin belajar itu susah ..." (SF diwawancara pada tanggal 01 Februari 2020 Pukul 18:00)

"Anak tantrum kita harus bagaimana nah itu yang dulu ya mba, anak emosinya sedang meledak-ledak sedang marah, nah itu ya kita pasti ada lah banyak ngerasain juga emosi marah emosi kesal ..." (S - diwawancara pada tanggal 31 Januari 2020 Pukul 08:30)

Dari hasil wawancara tersebut bahwasannya dalam mendampingi siswa autis banyak menghadapi tantangan yang dimana tantangan tersebut juga bisa menguras emosi pada guru pendamping siswa autis. Emosi yang dirasakan oleh guru pendamping saat mendampingi siswa autis terutama saat perilaku tantrumnya muncul bisa berupa marah dan kesal. Selain itu, guru pendamping siswa autis yang harus menghadapi berbagai perilaku siswa autis yang beranekaragam dan rentang waktu munculnya perilaku tersebut tidak dapat ditentukan yang menjadikan guru pendamping siswa autis memiliki keunikan atau kekhasan tersendiri dalam mendampingi siswa autis dibandingkan dengan pendampingan siswa berkebutuhan khusus lainnya.

Pada saat mendampingi siswa autis, guru pendamping menggambarkan emosi negatif yang dirasakannya dalam bentuk sebagai marah, terkejut, dan heran. Emosi yang dirasakan tersebut dilihat dari respon fisik berupa mata yang memelotot dan intonasi suara tinggi. Selain itu, emosi negatif tersebut juga diwujudkan dalam gerakan tubuh berupa menghentakkan kaki ke lantai serta berdecak (Khaerunnisa, dkk. 2019).

Salah satu sekolah inklusi di Kota Jambi yang akan peneliti jadikan objek lokasi penelitian yaitu SD Negeri 131/IV Kota Jambi. Terdapat beberapa anak berkebutuhan khusus dengan berbagai jenis 
kategori. Sekolah ini sudah menjadi sekolah inklusi selama kurang lebih 11 tahun. Sekolah ini dipilih menjadi lokasi penelitian oleh peneliti karena sekolah ini mengutamankan perhatian dan kepedulian guru pendamping kepada siswa berkebutuhan khusus yang didampingi, serta jumlah siswa berkebutuhan khusus terutama siswa autis di sekolah ini yang banyak membuat peneliti memilih sekolah ini untuk dilakukannya penelitian.

Tabel 1.1. Data Siswa Autis di SD Negeri 131/IV Kota Jambi

\begin{tabular}{cccc}
\hline No. & $\begin{array}{c}\text { Inisial nama } \\
\text { siswa }\end{array}$ & $\begin{array}{c}\text { Jenis } \\
\text { Kelamin }\end{array}$ & Kelas \\
\hline 1. & TM & L & I \\
2. & SPA & P & I \\
3. & DAK & L & I \\
4. & MA & L & I \\
5. & RZDP & L & III \\
6. & JFS & L & IV \\
7. & DZ & P & IV \\
8. & NMS & L & VI \\
9. & MNFM & L & VI \\
\hline
\end{tabular}

Sumber: Nama Siswa PDBK di SD Negeri 131/IV Kota Jambi Tahun Ajaran 2019/2020

Sehubungan dengan data tersebut bahwasannya sekolah inklusi tentu membutuhkan tenaga pengajar yang mampu mendampingi anak berkebutuhan khusus dalam proses pembelajaran. Guru pembimbing khusus merupakan salah satu penanggung jawab dan memiliki peran penting dalam memenuhi kebutuhan serta terjadinya interaksi yang intens antara guru pendamping dan anak berkebutuhan khusus di sekolah inklusif. Menjadi guru pendamping anak berkebutuhan khusus terutama autisme tidaklah mudah. Peran yang diberikan berbeda dengan guru pada umumnya (Wardah, 2019).

Pada SD Negeri 131/IV Kota Jambi memiliki guru pendamping sebanyak 30 orang guru pendamping. Jumlah tersebut sudah termasuk dengan jumlah guru pendamping autis sebanyak 9 orang guru pendamping. Sehubungan dengan hal di atas sejalan dengan hasil wawancara peneliti bersama salah satu guru pendamping yaitu SF yang bertugas mendampingi siswa autis di SD Negeri 131/IV di Kota jambi.

“... Terus juga kita belajar mengenai pelajaran dia dikelas misalnya tentang bagian apa gitu. nah itu kita juga mempelajarinya dan menguasai materinya baru dikasih tahu ke anaknya ..." (SF diwawancara pada tanggal 01 Februari 2020 Pukul 18:00)

Berdasarkan hasil wawancara
tersebut bahwasannya tugas guru pendamping tidak hanya mendampingi anak berkebutuhan khusus saja, akan tetapi juga memiliki tugas-tugas tertentu yang sudah menjadi tanggung jawab dari guru pendamping tersebut. Selain tugas-tugas tersebut guru pendamping juga memiliki tantangan yang banyak menguras emosi yang setiap harinya harus mereka lewati, terutama dalam menghadapi berbagai macam karakter dari anak berkebutuhan khusus.

Emosi itu sendiri merupakan suatu stimulus yang mengaitkan dengan adanya transformasi pada wajah dan juga tubuh, aktivitas yang terjadi pada otak, evaluasi kognitif, perasaan yang subjektif, dan keinginan untuk melakukan suatu aktivitas, yang dimana hal tersebut dibentuk seluruhnya oleh kebijakan yang terdapat di suatu kultur (Wade, 2007). Emosi yang terdapat dalam diri manusia terdiri dua kategori emosi, yaitu emosi negatif dan emosi positif. Emosi diartikan sebagai sebuah reaksi tidak menyenangkan atau menyenangkan yang dirasakan oleh individu terhadap suatu kejadian tertentu. Reaksi yang tidak menyenangkan terhadap suatu kejadian disebut dengan emosi negatif sedangkan reaksi menyenangkan terhadap suatu kejadian disebut emosi positif (Mashar, 2007).

Emosi positif memiliki fungsi penting dalam evolusi manusia menuju kebahagiaan, yaitu dengan menggerakkan 
manusia, menginvestasikan sumber daya yang dimiliki saat ini, demi membangun sesuatu yang lebih baik yang akan sangat bernilai pada masa depan. Emosi positif mampu memperlebar atensi, membuka pikiran dan hati pada berbagai situasi kemungkinan dan juga kesempatan. Emosi positif memiliki fungsi sebagai koping dari tiga hal. Pertama, emosi positif dapat membantu individu dalam menghadapi berbagai permasalahan. Hal tersebut dikarenakan emosi positif dapat membantu individu agar lebih berpikir positif dan objektif. Kedua, emosi positif serta dukungan sosial sangat berkaitan, yang dimana untuk meningkatkan kondisi kestabilan emosi individu dapat dibantu melalui dukungan sosial. Ketiga, emosi positif dapat meningkatkan potensi dalam menangani psikosomatis (Fredrickson, 2009).

Terdapat empat jenis emosi positif menurut Fredrickson (1998), diantaranya:

1. Kegembiraan (Joy)

Joy atau kegembiraan sering disebut dengan kebahagiaan yang juga termasuk dalam emosi positif dan hal tersebut kemunculannya relatif tinggi jika dikaitkan dengan salah satunya hiburan. Perasaan gembira muncul pada saat kondisi yang erat dengan kedamaian dan kenyamanan dengan kondisi lingkungannya serta tidak membutuhkan usaha yang begitu sulit.

\section{Ketertarikan (Interest)}

Ketertarikan atau interest sering dikaitkan dengan rasa keingintahuan individu akan suatu hal. Ketertarikan dapat di rasakan ketika keterampilan yang dimiliki individu sesuai dengan tantangan yang akan di hadapi. Ketertarikan termasuk dalam emosi positif yang sering dialami. Ketertarikan muncul dengan tidak di sertainya perlakuan fisik yang jelas, namun dapat muncul saat kondisi yang bersemangat dan keinginan untuk menyelidiki hal yang baru dari suatu objek.

\section{Kepuasan (Contentment)}

Kepuasan disebut juga dengan terpenuhinya gairah individu atau biasa dikaitkan dengan perasaan lega. Kepuasan timbul dalam kondisi yang meyakinkan atau pasti. Kepuasan yang biasa dirasakan individu lebih bersifat kognitif ketimbang fisik. Kepuasan dapat menstimulasi individu untuk tetap menikmati hidup mereka saat sekarang serta menikmati keberhasilan yang sudah diperolehnya.

4. Cinta (Love)

Cinta menjadi salah satu emosi positif yang paling sering di rasakan oleh setiap individu. Perasaan cinta muncul pada saat kondisi individu menjalin sebuah hubungan dengan individu lain.

Seligman (2005) mengungkapkan terdapat tiga faktor yang mampu mempengaruhi emosi positif, diantaranya:

1. Lingkungan

Individu yang memiliki sikap keterbukaan dan banyak melakukan interaksi sosial dengan lingkungan sekitar dapat meningkatkan kebahagiaan dalam dirinya. Sikap terbuka yang dibangun mampu menciptakan relasi sosial yang luas sehingga dapat memicu munculnya dorongan secara sosial baik itu dari keluarga dan lingkungan.

2. Rasa Syukur

Individu menyampaikan rasa terima kasih kepada orang lain sebagai bentuk rasa syukur yang di rasakan oleh diri yang di karenakan telah memberikan kepuasaan terhadap kehidupannya. Rasa syukur tidak hanya diberikan kepada orang lain, melainkan juga kepada Sang Maha Pencipta.

3. Religius

Individu yang religiusnya cenderung tinggi bisa di katakan cenderung bahagia dan banyak merasakan kepuasan terhadap kehidupannya dibandingkan dengan individu yang religiusnya rendah. 
Agama hadir ditengah kalangan manusia mampu menaruh harapan akan masa depan dan menciptakan makna dalam kehidupan.

Pada guru pendamping siswa autis akan mengalami stres jika memaknai pekerjaannya sebagai guru pendamping siswa autis lebih banyak dipengaruhi emosi yang berupa marah, kesal, sedih dan merasa lelah. Hal tersebut sudah terbukti oleh apa yang dikatakan oleh responden $\mathrm{S}$ dalam wawancara tersebut menyangkut emosi yang banyak dirasakan oleh guru pendamping saat mendampingi siswa autis. Hal tersebut juga di jelaskan oleh Fredrickson (1998) bahwa emosi positif hendaklah senantiasa ditumbuhkan dalam diri setiap manusia. Hal ini karena emosi positif berperan ketika orang tersebut mengalami stres dalam membantu mengurangi akibat stres yang ditimbulkan.

Berdasarkan pemaparan di atas, dalam penelitian ini peneliti ingin melihat dan mengetahui gambaran dari emosi positif yang dirasakan dan didapat serta pemaknaan emosi positif pada guru pendamping siswa autis bagi kehidupannya dimasa sekarang dan akan datang dan faktor-faktor apa saja yang mempengaruhi pembentukkan emosi positif. Hasil penelitian ini diharapkan dapat bermainfaat bagi peneliti, guru pendamping autisme serta para pembaca.

\section{Metode}

Penelitian ini bertujuan untuk mengetahui gambaran emosi positif pada guru pendamping siswa autis di SD Negeri 131/IV Kota Jambi. Dalam menggali data secara mendalam dan penggambaran data secara deskriptif diperlukan metode yang mampu menunjang terlaksananya penelitian ini. Oleh karena itu, pendekatan penelitian kualitatif dianggap tepat untuk menggali data tersebut. Selain itu, keterbatasan jumlah subjek dalam penelitian ini juga menjadi alasan digunakannya pendekatan kualitatif dengan metode fenomenologi. Partisipan dalam penelitian dipilih dengan menggunakan teknik purposive sampling. Adapun kriterianya sebagai berikut:

a. Guru pendamping siswa autis di SD Negeri 131/IV Kota Jambi

b. Berusia 25-55 tahun

c. Mendampingi secara langsung siswa autis

d. Sudah bekerja minimal 3 tahun

Jumlah partisipan yang akan peneliti wawancarai adalah 4 orang partisipan yang sesuai dengan kriteria yang telah ditentukan. Untuk mendapatkan data dari penelitian ini dengan mengumpulkan data mendalam pada subjek melalui wawancara terbuka dan instrumen pendukung berupa observasi. Peneliti menggunakan teknik analisis data dengan Interpretative Phenomenological Analysis (IPA).

\section{Hasil}

Data profil memuat identias partisipan M, S, L, dan T. Partisipan M telah menjadi guru pendamping siswa autis sejak tahun 2017. Berawal dari menjadi seorang terapi lalu berhenti dan memutuskan untuk menjadi guru pendamping siswa autis pribadi yang ditunjuk langsung oleh orang tua siswa autis SD Negeri 131/IV Kota Jambi. Sebelum menjadi guru pendamping siswa autis, $M$ awalnya hanya seorang ibu rumah tangga, lalu memilih bekerja sebagai guru madrasah di daerah tungkal kurang lebih 5 tahun dan melanjutkan bekerja menjadi guru TK selama hampir 4 tahun. Partisipan $S$ seorang ibu rumah tangga dan juga menjadi guru pendamping siswa autis pribadi. Sebelum menjadi guru pendamping siswa autis $\mathrm{S}$ merupakan seorang guru yang memberikan bimbingan belajar secara privat kepada siswa sekolah dasar selama 2 tahun. Kemudian $\mathrm{S}$ bekerja menjadi terapis di sebuah yayasan di kota jambi dan mulai tahun 2008 partisipan S sudah menjadi guru pendamping siswa autis yang ditempatkan di SD Negeri 131/IV Kota Jambi, namun beberapa tahun kemudian $\mathrm{S}$ memutuskan untuk guru pendamping siswa autis pribadi yang tidak terikat lagi dengan yayasan 
tetapi masih mendampingi siswa autis di SD Negeri 131/IV Kota Jambi. Partisipan L menjadi guru pendamping siswa autis sejak tahun 2015. Berawal dari seorang terapis lalu lanjut menjadi guru pendamping siswa autis di sekolah. Awal mula menjadi guru pendamping siswa autis di sekolah dasar di daerah mayang, lalu pernah menjadi guru pendamping siswa autis di TK dan akhirnya menjadi guru pendamping siswa autis di SD Negeri 131/IV Kota Jambi hingga kini. Partisipan $\mathrm{T}$ selain menjadi guru pendamping siswa autis, juga menjaga dan merawat orang tuanya di rumah. T menikah ketika dirinya masih duduk dibangku kuliah dan di saat berada di bangku kuliah itu lah $\mathrm{T}$ ditawarkan menjadi terapis di tempat ia melakukan penelitian skripsinya. Sejak tahun $2013 \mathrm{~T}$ resmi menjadi terapis dari sebuah yayasan dan kemudian menjadi guru pendamping di SD Negeri 131/IV Kota Jambi. T kemudian sempat pindah kerja di sebuah tempat penitipan anak namun karena tidak betah akhirnya $\mathrm{T}$ kembali menjadi guru pendamping siswa autis.

Temuan yang didapat dari keempat partisipan terdiri dari tujuh tema, diantaranya: Perasaan gembira, ketertarikan, kepuasaan diri, cinta, daya juang, kebersyukuran, dan simpati. Penjelasan tersebut dijelaskan rinci pada bagian di bawah ini:

1) Perasaan gembira

Temuan ini menjelaskan bahwa terdapat perasaan senang, perasaan asyik, enjoy, terhibur, tersanjung, mood bagus dan naik, seru. Hal tersebut terjadi karena terdapat momen yang menyenangkan bersama siswa autis yang didampinginya. Momen tersebut tentu membuat guru pendamping siswa autis merasakan perasaan gembira.

2). Ketertarikan.

Temuan ini menjelaskan adanya rasa penasaran, haus akan ilmu baru, dan ingin mendapatkan hal baru.

3) Kepuasan Diri

Kepuasan diri merupakan perasaan bangga dan lega yang dirasakan oleh partisipan selama menjadi guru pendamping siswa autis. Kepuasan timbul dalam kondisi yang meyakinkan atau pasti. Kepuasan yang biasa dirasakan individu lebih bersifat kognitif ketimbang fisik. Kepuasan dapat menstimulasi individu untuk tetap menikmati hidup mereka saat sekarang serta menikmati keberhasilan yang sudah diperolehnya.

\section{4). Cinta.}

Temuan ini mengatakan bahwa partisipan merasa jatuh cinta kepada siswa autis yang didampinginya. Jatuh cinta dalam arti sebagai guru yang dipenuhi kasih sayang pada siswanya.

\section{5). Daya Juang}

Pada temuan ini, hal-hal yang melatarbelakangi para partisipan memiliki perasaan daya juang antara lain partisipan selalu berusaha untuk mencari tahu bagaimana cari mengatasi siswa autis, terus belajar mengenai siswa autis, adanya perasaan bersemangat, partisipan juga merasakan perasaan capek tenaga dan pikiran, selama mendampingi siswa autis partisipan merasa dirinya menjadi kuat fisik dan mental, menjadi disiplin, dan terdapat dampak positif.

\section{6). Kebersyukuran}

Temuan ini mengungkapkan bahwa emosi positif berkaitan erat dengan adanya kebersyukuran. Hal ini ditandai dengan adanya rasa syukur yang dimiliki oleh partisipan, perasaan syukur juga harus disertai oleh rasa ikhlas dan sabar selama mendampingi siswa autis.

\section{7). Simpati}

Simpati dalam penelitian ini. Dimaksudkan bahwa partisipan menghargai orang tua siswa autis, siswa autis tidak selalu memberikan kesan buruk, memaklumi siswa autis dan orang tuanya, respect, menerima resiko pekerjaan, serta merasa kasihan terhadap siswa autis yang tidak diterima di sekolah formal

\section{Pembahasan}

Emosi positif pada guru pendamping siswa autis di SD Negeri 131/IV Kota 
Jambi memiliki persamaan dengan teori emosi positif yang dikemukakan oleh Fredrickson (1998). Persamaan tersebut dapat terlihat dari temuan peneliti mengenai emosi positif yang ditunjukkan oleh guru pendamping siswa autis di SD Negeri 131/IV Kota Jambi yaitu perasaan gembira, ketertarikan, kepuasan diri, dan cinta. Terdapat pula perbedaan mengenai emosi positif pada guru pendamping siswa autis di SD Negeri 131/IV Kota Jambi ada tiga temuan, yaitu berdaya juang, kebersyukuran, dan simpati. Temuan tersebut tidak dikemukakan oleh Fredrickson (1998).

Adapun hubungan tersebut ditunjukkan oleh emosi positif pada guru pendamping siswa autis di SD Negeri 131/IV Kota Jambi berupa perasaan gembira. Penjelasan dari relevansi temuan dengan teori Fredrickson (1998) mengenai kegembiraan, yang dimana teori tersebut menjelaskan perasaan gembira muncul pada saat kondisi yang erat dengan kedamaian dan kenyamanan dengan kondisi lingkungannya serta tidak membutuhkan usaha yang begitu sulit. Hal tersebut biasa ditemukan saat individu berhasil mendapatkan sebuah pencapaian. Interaksi dengan individu lain juga termasuk dalam salah satu cara untuk mendapatkan kegembiraan.

Temuan berikutnya yang berkaitan dengan ketertarikan. Ketertarikan yang dimaksud adalah adanya rasa penasaran, haus akan ilmu baru, tertarik, dan ingin mendapatkan hal baru. Hal tersebut berkaitan dengan yang dikemukan oleh Fredrickson (1998) yang mengatakan ketertarikan dirasakan ketika individu yang tertatik untuk melakukan eksplorasi hal baru dapat memperbarui dan membuka pemikirannya sendiri. Pengetahuan dan pengalaman yang didapatkan dari hasil eksplorasi dimanfaatkan untuk menghadapi peristiwa yang akan datang.

Pada temuan selanjutnya adalah mengenai kepuasan diri. Kepuasan diri yang dimaksud adalah perasaan bangga dan lega yang dirasakan oleh partisipan selama menjadi guru pendamping siswa autis. Penjelasan tersebut berkaitan dengan teori Fredrickson (1998) yang mengungkapkan bahwa kepuasan diri juga muncul dengan terpenuhinya gairah individu atau biasa dikaitkan dengan perasaan lega.

Temuan berikutnya yang ditunjukkan oleh emosi positif pada guru pendamping siswa autis di SD Negeri 131/IV Kota Jambi yaitu cinta. Penjelasan tersebut berhubungan dengan teori dari Fredrickson (1998) mengenai cinta, yang dimana cinta menjadi salah satu emosi positif yang paling sering di rasakan oleh setiap individu. Perasaan cinta muncul pada saat kondisi individu menjalin sebuah hubungan dengan individu lain. Cinta bisa di bagi menjadi dua, yaitu hubungan cinta dan pengalaman cinta.

Kebersyukuran sejalan dengan penelitian yang dilakukan oleh Shobihah (2014) yang mengungkapkan bahwa kebersyukuran didorong juga dengan adanya ikhlas dan sabar, yang dimana kebersyukuran memiliki hubungan positif dengan emosi positif.

Hal tersebut sejalan dengan penelitian Pekrun, Goetz, Titz, dan Perry (2002) yang memaparkan berbagai macam emosi yang dapat digolongkan sebagai emosi positif dan emosi negatif. Pada pemaparannya tersebut menjelaskan simpati merupakan bagian dari emosi positif yang termasuk ke dalam kategori sosial.

Partisipan yang memiliki emosi positif tentunya meyakini bahwa terdapat faktor yang mempengaruhi dirinya untuk bisa merasakan emosi positif. Dalam temuan dilakukan oleh peneliti, terdapat enam faktor yang mempengaruhi pembentukan emosi positif pada guru pendamping siswa autis di SD Negeri 131/IV Kota Jambi. Diantaranya fakor lingkungan, kerja sama, kemampuan diri, pengalaman kerja, motivasi internal, dan faktor kepribadian.

Seligman (2005) mengungkapkan faktor lingkungan sebagai faktor yang penting dalam pembentukkan emosi positif. 
Faktor ini muncul pada individu yang memiliki sikap keterbukaan dan banyak melakukan interaksi sosial dengan lingkungan sekitar dapat meningkatkan kebahagiaan dalam dirinya. Sikap terbuka yang dibangun mampu menciptakan relasi sosial yang luas sehingga dapat memicu munculnya dorongan secara sosial baik itu dari keluarga dan lingkungan. Hal ini relevan dengan faktor emosi positif pada guru pendamping siswa autis di SD Negeri 131/IV Kota Jambi, yang mana pada partisipan terdapat pengaruh wali murid, penilaian orang lain, dan kedekatan partisipan dengan siswa autis yang didampinginya.

Berdasarkan hubungan antara kajian di atas, terdapat juga perbedaan antar kajian tersebut. Perbedaan tersebut sekaligus menjadi unsur komplemen dan kebaruan dari penelitian ini. Faktor tersebut berkaitan dengan kerja sama, kemampuan diri, pengalaman kerja, rasa ingin tahu, motivasi internal, dan kepribadian. Sebagai seorang guru pendamping siswa autis yang memiliki peran yang penting dalam kemajuan proses belajar siswa autis, guru pendamping siswa autis diberi kesempatan untuk memberikan ilmu dan pengalamannya untuk mendampingi siswa autis.

\section{Kesimpulan}

Berdasarkan hasil penelitian yang telah dilakukan, dapat ditarik kesimpulan bahwa adanya emosi positif pada guru pendamping siswa autis di SD Negeri 131/IV Kota Jambi berupa perasaan gembira, kepuasan diri, ketertarikan, cinta, berdaya juang, kebersyukuran, dan simpati. Adapun faktor yang mempengaruhi emosi positif pada guru pendamping siswa autis di SD Negeri 131/IV Kota Jambi terdiri dari lingkungan, kerja sama, kemampuan diri, pengalaman kerja, motivasi internal, dan kepribadian.

Terdapat keunikan dan perbedaan dari teori dan temuan yang sudah ada sebelumnya yaitu dalam penelitian emosi positif pada guru pendamping siswa autis ditemukan adanya daya juang, kebersyukuran, dan simpati.

\section{Saran}

Saran pada penelitian ini di tunjukkan kepada:

1. Partisipan penelitian

Bagi semua partisipan disarankan dapat meningkatkan emosi positif yang dirasakannya agar pekerjaan yang dijalankan mendapatkan hasil ke diri sendiri yang lebih baik.

2. Pihak sekolah

Bagi pihak sekolah disarankan mampu memberikan wawasan baru mengenai emosi positif terutama bagi guru pendamping siswa autis agar bisa untuk memberikan pelatihan kepada guru pendamping.

3. Peneliti selanjutnya

Bagi peneliti selanjutnya, disarankan agar lebih memperdalam teori dan penggalian informasi mengenai emosi positif dari sudut pandang yang berbeda terhadap guru pendamping lainnya.

\section{Daftar Pustaka}

Desiningrum. D. R. (2016). Psikologi Anak Berkebutuhan Khusus. Yogyakarta: Psikosain.

Fredrickson, B. L. (2009). Positivity. The Journal Of Positive Psychology, 4(6), 578-580.

Fredrickson, B. L. (1998). What Good Are Positive Emotions? Review of General Psychology. 56 (3), 218-226.

Khaerunnisa, S. H., Hakim, L., \& Erliana, Y. D. (2019). Regulasi Emosi Guru Pendamping Anak Berkebutuhan Khusus Di Sdit Insan Qurani Sumbawa Besar. Jurnal

Psimawa, 2(1), 7-14.

Kumpulan Data Sekolah Inklusi Direktorat Pembinaan PKLK Kemendikbud 2019, di akses melalui 
Mashar, R. (2007). Emosi Positif Anak Usia Dini Dan Stimulasi "Aku Anak Ceria". Indigenous, Jurnal Ilmiah Berkala Psikologi. Vol. 9, No. 1.

Murtie, A. (2017). Ensiklopedi Anak Berkebutuhan Khusus. Yogyakarta: Redaksi Maxima.

Pekrun, R., Goetz, T., Titz, W., \& Perry, R. P. (2002). Positive emotions in education. In E. Frydenberg (Ed.), Beyond coping: Meeting goals, visions, and challenges, 149-173.

Saputra, A. (2016). Kebijakan Pemerintah Terhadap Pendidikan Inklusif. Golden Age: Jurnal Ilmiah Tumbuh Kembang Anak Usia Dini, 1(3), 1-15.

Seligman. M. E. P. (2005). Authentic Happiness: Menciptakan kebahagiaan dengan psikologi positif. Bandung: Mizan Media Utama.

Shobihah, I. F. (2014). Kebersyukuran (Upaya Membangun Karakter Bangsa Melalui Figur Ulama). Jurnal Dakwah, 15(2), 383-406.

Undang-Undang Republik Indonesia Nomor 70 Tahun 2009 Tentang Pendidikan Inklusi.

Usop. D.S,. Misyanto. R. A,. (2017). Karakteristik Anak Berkebutuhan Khusus Di Sekolah Dasar Negeri (Inklusi) Di Kota Palangka Raya. Anterior Jurnal. Vol. 17, Issue. 1, hal 22-27.

Widiastuti. D,. (2014). Perilaku Anak Berkebutuhan Khusus Gangguan Autisme Di SLB Negeri Semarang Tahun 2014. BELIA. Vol. 3, No. 2. 